\title{
Increasing Local Farmers Sustainability Index Status to Preserve Agricultural Sustainability
}

\author{
Hanipah $^{1}$, Hayati Sari Hasibuan*2, Rudy P. Tambunan ${ }^{3}$ \\ hanipahtanjung@gmail.com ${ }^{1}$, hayati.hasibuan@ui.ac.id ${ }^{* 2}$,rudyptamb@yahoo.com \\ School of Environmental Science, University of Indonesia, Jakarta, 10430 ${ }^{1,2}$, Department of \\ Geography, University of Indonesia, Depok ${ }^{3}$
}

\begin{abstract}
In recent years, there has been land-use changes from the paddy field to the industrial and housing in Karawang. The proportion of paddy fields changed from $55.35 \%$ (2009) to $54.49 \%$ (2017). Industries also attracted people to switch professions from farming to the industrial. Indicated by the decreasing number of workers in the farming, from 4,628 people (2009) to 3,744 people (2010) and increasing in the industrial, from 89,163 people (2009) to 242,896 people (2016). The purpose of study is to measure the index of farmers' sustainability status. The study uses the MultiDimensional Scaling method with 3 dimensions: social, economic and environmental. The results found that the economic dimension has the lowest index. The most problem in the economic dimension is the high capital for production. The social dimension showed that farmers have no re-generation. Moreover, the environment dimension showed that almost $40 \%$ of the farmers have no land, and the most critical issue to deal with are access to the irrigation to increase the rice-production.
\end{abstract}

Keywords: Farmer; Index status; Karawang's farmers; Profession transition; Sustainability

\section{Introduction}

Karawang regency as one of the rice barns in West Java and in national scale is a agricultural area that need to be protected for sustainability. However, massive urbanization contribute to the decrease of land supply and as a result, more than $25 \%$ of agricultural land use have been converted to industrial use, commercial, or residential to meet the increasing of land demand [1]. That phenomenon occurred in Jakarta, which led to the development of suburban areas, as reflected by the expansion of the built up area on the outskirts of Jakarta [18] including Karawang Regency. Karawang Regency has strategic location near the capital Jakarta and crossed by the national road lead Karawang as one of the investors targets in developing industrial and urban built up area such as shopping centers and housing. As a result of the urban expansion, Karawang Regency was planned as one of the target cities to be industrial expansion. It mentioned in some legislation, such as in National Industrial Development Master Plan 2015 - 2035 as Industrial Growth Center Area (WPPI) [15] and mentioned in the Peraturan Daerah Kabupaten Karawang No. 2 Tahun 2013 tentang Rencana Tata Ruang Wilayah tahun 2011-2031.

Urbanization and industrialization require land in the process that led to conversion of productive agricultural land. From the period 2009 to 2017, agricultural land, especially paddy 
fields in Karawang reduced 1501 ha [2][4]. The total lose of paddy field area equivalent to $25 \%$ of the average area of the one district in Karawang.

The consequence of land use change that originally agricultural areas to industrial development areas, both industrial areas and large industrial and other manufacturing perceived by local people, directly or indirectly, positively or negatively. Farmers as the main actors and directly manage the paddy field feel the effects of agricultural land use change. Although, generally in economic aspects the industries provide more employment opportunities that can help to gain more incomes and welfare of the community. It showed from the number of workers in the industrial sector in Karawang Regency in 2009 were 89.163 people increase to 242.896 people in 2016 [2][3].

However, on the other side the industries existence have negative impact that perceived by people's around the industrial area. Industrial activities on environmental aspects could pollute the environment, such as river water pollution. Polluted river water is used as a source of irrigation. In addition, the growing number of industries make water demand in the industrial sector increased and caused the proportion of irrigation water reduced. This lead to insufficiency of irrigation water demand. The loss of water for agriculture will affect the productivity of paddy fields due to drought. Then, the impact is also felt on the social and economic aspects of farmers. Because of the changing in agricultural environment, caused unproductive land and lead farmers lose income. Loss of income caused by the drought of land can lead to eliminate the profession of farmers in managing wetland and loss of interest of the community especially the young generation to involve in wetland management. It showed from reduced number of farmers in 1 year period (2009 to 2010) from 4,628 people to 3,744 people [5][6] in one location, West Telukjambe District. Most of the effects which previously mentioned shows that the existence and sustainability of farmers in managing their paddy field threatened. Therefore, this research aimed to measure the sustainability index of farmers, especially rice paddy fields farmers. The farmers sustainability is determined from the environment and their welfare. Welfare is a situation where the person's needs are met, freedom, and achieve a better quality of life [11]. There are five indicators of well-being [9]. Those indicators are income, education, employment, housing, and health. In addition, there are three-dimensional measuring well-being that is material, social and human [24]. Dimensions and indicators are organized into several dimensions and attributes to gauge the sustainability of farmers in this study.

There are a number of studies concerning farmer's sustainability such measured the sustainability of soybean farming from economic aspect in Central Java [20], study about sustainability of agricultural landscape in West Java using spatial analysis [22], and researched about farmers capability to achieved sustainable agriculture [21]. Thus the purpose of this study is to measure and analyze the index of farmers' sustainability status. In this study, the degree of farmers sustainability measured by creating and scoring some dimensions and attributes based on literatures and current practices.

\section{Methods}

The research was conducted in the West Telukjambe District, Karawang Regency, West Java Province (Figure 1). West Telukjambe is located in the southwest of Karawang Regency lacated between $6^{\circ} 29944^{\prime}-$ 6o39275' East Longitude and 107²2364 '- 107'26659 Southern 
Latitude [6]. Northern and western of West Telukjambe borders Bekasi Regency. West Telukjambe District consist of $73.36 \mathrm{~km}^{2}$ area and located at an average altitude of 57 meters. This research was conducted in August - September 2019.

The population in this study is farmers. farmers included in this population is someone whose work in the field of management of rice paddy fields and each person represents one household. The number of samples is determined using Slovin formula and total population of 2.494 farmers then obtained sample 96 farmers. The number of samples per village determined proportionally. Data used in the study are primary data obtained from the questionnaires.

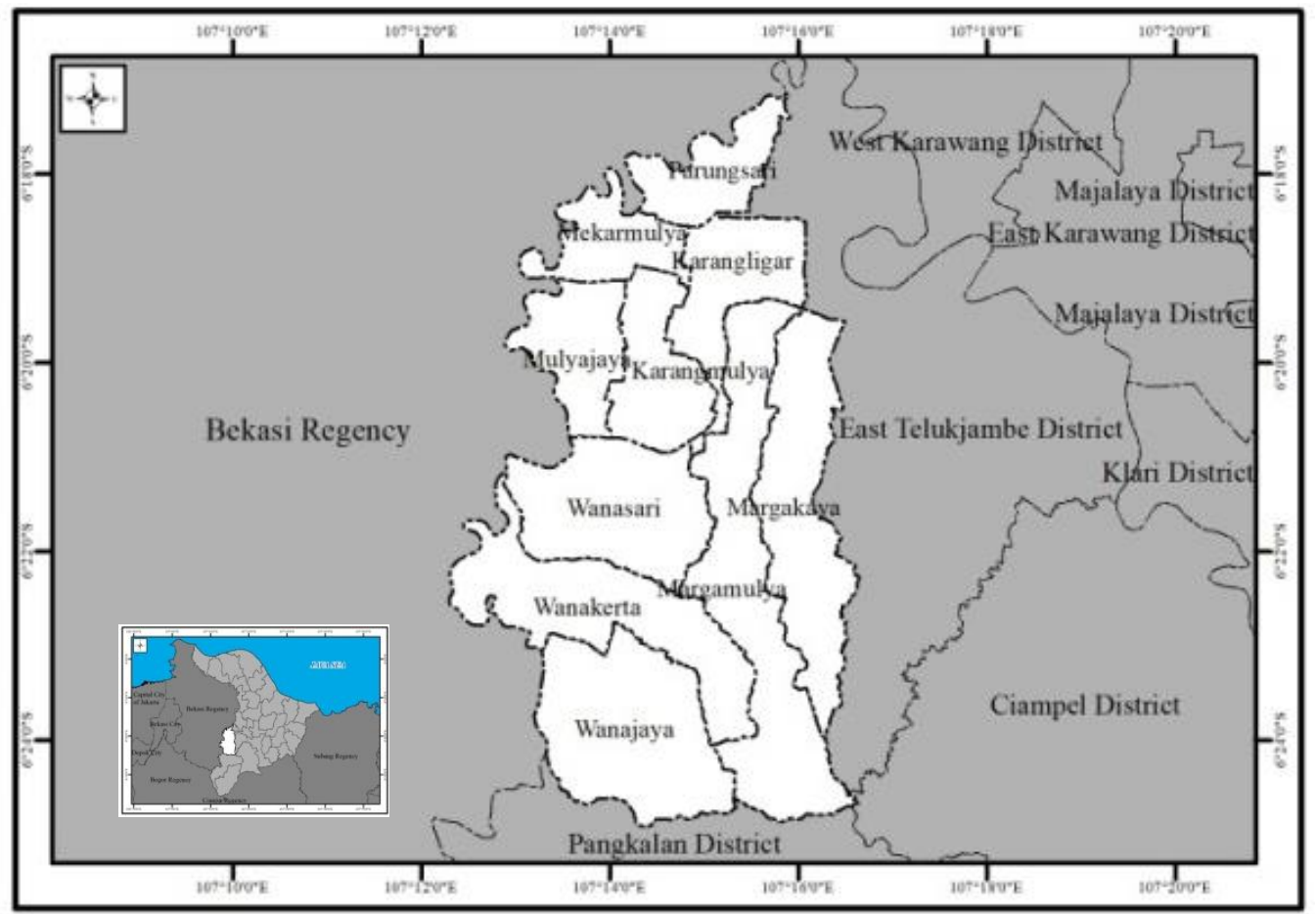

Fig. 1. Location of research West Telukjambe District of Karawang Regency

After primary data obtained and collected from the questionnaire then processing the data from questionnaire. Data from the questionnaire is processed using Multi-Dimensional Scalling with Rapfish tools which in this study modified as Rapfarmers to get the index value of sustainability. The MDS approach was chosen because quite stable compared to the method other multivariate [16]. Rapfish chosen as a tools for this study because of it main function as a tools to evaluate sustainability [13]. Before the secondary data is processed, determined the 3 dimensions and attribute that is enviroment, economic and social. The attributes used in each dimension derived from some literature related to farmer sustainability [7][8][19][12][14][23]. In this study is set at 34 attributes. The number of attributes of each dimension is 11 environment attributes, 10 economy attributes, and 13 social attributes. Each attribute is given a scoring as showed in Table 1. 
Next is the analysis of leverage to obtained the sensitivity of each attribute and that have a significant impact on the sustainability index in each dimension. Sensitive attributes known by changing the RMS value if the value higher if an attribute is removed, these attributes have a significant role in sustainability. Then Monte Carlo analysis, to estimate the effect of the error with a confidence level of $95 \%$. The next step is to determine whether the model has been simulated in good category or not by looking at the value of the $\mathrm{S}$-stress and $\mathrm{R}^{2}$ of simulation. The simulation results in good category if the value of the $\mathrm{S}$-stress $<0.25$ and $\mathrm{R}^{2}$ close to 1 [17].

Table 1. Dimensions, attributes, and scoring MDS of Rapfish

\begin{tabular}{|c|c|c|c|c|}
\hline \multirow[t]{3}{*}{ No. } & \multicolumn{4}{|c|}{ MDS analysis dimensions and attributes along with the score } \\
\hline & \multirow{2}{*}{$\begin{array}{l}\text { Dimensions/ } \\
\text { attributes }\end{array}$} & \multicolumn{2}{|c|}{ Scoring } & \multirow[t]{2}{*}{ Remarks questions and score } \\
\hline & & Good & $\mathrm{Bad}$ & \\
\hline A & Environment & & & \\
\hline 1 & $\begin{array}{l}\text { Type of land } \\
\text { ownership }\end{array}$ & 2 & 0 & $\begin{array}{l}\text { What kind of land ownership are processed? (0) claim; (1) } \\
\text { leases; (2) personal (Hayati, et al., 2010) }\end{array}$ \\
\hline 2 & $\begin{array}{l}\text { Area of land } \\
\text { ownership }\end{array}$ & 5 & 0 & $\begin{array}{l}\text { How much land owned? (0) } 0 \text { ha; (1) } 0.1-0.5 \text { ha; (2) } 0.51 \text { to } 1 \\
\text { ha; (3) } 1.1-1.5 \text { ha; (4) } 1.51 \text { to } 2 \text { ha; (5)> } 2 \text { ha (BPS, 2017) }\end{array}$ \\
\hline 3 & $\begin{array}{l}\text { Fertilizer } \\
\text { subsidies }\end{array}$ & 2 & 0 & $\begin{array}{l}\text { What type of fertilizer are easily available and used? (0) not } \\
\text { subsidized; (1) partially subsidized; (2) full subsidized (Ministry } \\
\text { of Agriculture, 2018) }\end{array}$ \\
\hline 4 & Pesticide intensity & 3 & 0 & $\begin{array}{l}\text { How often is the use of pesticides? (0) } 2 \text { times a week; ( } 1 \text { ) every } \\
1 \text { week; ( } 2 \text { ) every } 2 \text { weeks; ( } 3 \text { ) every } 3 \text { weeks (Reig-Martínez, et } \\
\text { al., 2011) }\end{array}$ \\
\hline 5 & Productivity & 4 & 0 & $\begin{array}{l}\text { What is the average productivity of the land?(0) 3-4ton / ha; (1) } \\
\text { 4-5ton / ha; (2) 5-6ton / ha; (3) 6-7ton / ha; (4)> 7ton / ha (BPS, } \\
\text { 2017) }\end{array}$ \\
\hline 6 & Irrigation type & 2 & 0 & $\begin{array}{l}\text { What type of irrigation?(0) rainfed; (1) semi-technical irrigation; } \\
\text { (2) technical irrigation (BPS, 2004) }\end{array}$ \\
\hline 7 & $\begin{array}{l}\text { irrigation water } \\
\text { source }\end{array}$ & 2 & 0 & $\begin{array}{l}\text { What is the source of water for irrigation?(0) springs; (1) water } \\
\text { wells; (2) surface water (Hayati, et al., 2010) }\end{array}$ \\
\hline 8 & $\begin{array}{l}\text { Irrigation } \\
\text { Physical } \\
\text { condition }\end{array}$ & 3 & 0 & $\begin{array}{l}\text { How is the physical condition of the existing irrigation } \\
\text { channels? }(0) \text { damaged (damage }>40 \%) \text {; (1) moderate damage } \\
\text { (damage } 21-40 \% \text { ); (2) with minor damage (damage 10-20\%); } \\
\text { (3) either (damage to }<10 \% \text { ) }\end{array}$ \\
\hline 9 & $\begin{array}{l}\text { The adequacy of } \\
\text { irrigation } \\
\text { discharge }\end{array}$ & 3 & 0 & $\begin{array}{l}\text { Is irrigation water discharge from the primary channel meets the } \\
\text { required discharge?(0); (1) Adequate but not up to the land; (2) } \\
\text { Adequate to the land by a pump; (3) sufficient and to the land } \\
\text { without the pump (Hayati, et al., 2010) }\end{array}$ \\
\hline 10 & Irrigation quality & 3 & 0 & $\begin{array}{l}\text { What is the quality of irrigation water obtained?(0)heavily } \\
\text { polluted; (1) polluted; (2) medium; (3) not polluted (Hayati, et } \\
\text { al., 2010) }\end{array}$ \\
\hline 11 & Seed certification & 3 & 0 & $\begin{array}{l}\text { What kind of quality seeds are easily available and often } \\
\text { used?(0) Poor, not certified; (1) Good, not certified; (2) Good } \\
\text { and mix; (3) good certified }\end{array}$ \\
\hline
\end{tabular}


Table 1. Dimensions, attributes, and scoring MDS of Rapfish

MDS analysis dimensions and attributes along with the score

\begin{tabular}{lll}
$\begin{array}{l}\text { No. Dimensions/ } \\
\text { attributes }\end{array}$ & Scoring & Remarks questions and score \\
& Good $\mathrm{Bad}$ & \\
\hline
\end{tabular}

\begin{tabular}{|c|c|c|c|c|}
\hline B & Economic & & & \\
\hline 1 & $\begin{array}{l}\text { Source of } \\
\text { capital }\end{array}$ & 2 & 0 & $\begin{array}{l}\text { Where the source of capital for farming / rice field management?(0) always } \\
\text { borrowed; (1) sometimes borrowed; (2) the person never borrow }\end{array}$ \\
\hline 2 & $\begin{array}{l}\text { Farm } \\
\text { income }\end{array}$ & 5 & 0 & $\begin{array}{l}\text { What is the total net income obtained from the farm per month? }(0)<1 \text { million; ( } 1 \text { ) } \\
1-2 \text { million; (2) } 2-3 \text { million; (3) } 3-4 \text { million; (4) } 4-5 \text { million; (5)> } 5 \text { million (Reig- } \\
\text { Martínez, et al., 2011) }\end{array}$ \\
\hline 3 & $\begin{array}{l}\text { Ownership } \\
\text { of farming } \\
\text { tools }\end{array}$ & 2 & 0 & $\begin{array}{l}\text { From where the equipment used to cultivate the land / farm? (0) all borrowed; (1) } \\
\text { partly borrowed; ( } 2 \text { ) All own property }\end{array}$ \\
\hline 4 & $\begin{array}{l}\text { The number } \\
\text { of } \\
\text { dependents }\end{array}$ & 3 & 0 & $\begin{array}{l}\text { How many family members who are dependents? }(0)>=5 \text { people; }(1) 2-4 \text {; (2) } 1 \text { (3) } \\
0\end{array}$ \\
\hline 5 & $\begin{array}{l}\text { Primary } \\
\text { expenses }\end{array}$ & 5 & 0 & $\begin{array}{l}\text { What are the costs incurred for basic needs per month? (0)> } 5 \text { million; (1) } 4-5 \\
\text { million; (2) 3-4 million; (3) } 2-3 \text { j million; (4) } 1-2 \text { million; (5) }<1 \text { million }\end{array}$ \\
\hline 6 & $\begin{array}{l}\text { adequacy of } \\
\text { income }\end{array}$ & 3 & 0 & $\begin{array}{l}\text { Is the income of farm enough for the cost of basic necessities?(0) not enough, often } \\
\text { borrowed; (1) sometimes borrowed; (2) not enough, never borrowed; (3) sufficient, } \\
\text { never borrow }\end{array}$ \\
\hline 7 & $\begin{array}{l}\text { Selling } \\
\text { price } \\
\text { grain }\end{array}$ & 2 & 0 & $\begin{array}{l}\text { Is the selling price grain corresponding meet standard price?(0) No; (1) Sometimes, } \\
\text { depending on the season; (2) always meet standard price (BPS, 2017) }\end{array}$ \\
\hline 8 & Total capital & 3 & 0 & $\begin{array}{l}\text { How much the costs incurred for the production of one season ?; (0)>7million; (1) } \\
6-7 \text { million (2) 5-6 million; (3) }<5 \text { million }\end{array}$ \\
\hline 9 & $\begin{array}{l}\text { Use of } \\
\text { income }\end{array}$ & 2 & 0 & $\begin{array}{l}\text { Used for any advantage obtained from the rice farming?(0) only for basic needs; (1) } \\
\text { can be used for children's education expenses; (2) able to staple, children's } \\
\text { education, and farm capital }\end{array}$ \\
\hline 10 & $\begin{array}{l}\text { Educational } \\
\text { ability }\end{array}$ & 3 & 0 & $\begin{array}{l}\text { Which is the highest education level could be achieved in the family?(0) Elementary } \\
\text { school; (1) junior high school; (2) senior high School; (3) college (Hayati, et al., } \\
\text { 2010) }\end{array}$ \\
\hline
\end{tabular}


Table 1. Dimensions, attributes, and scoring MDS of Rapfish

\begin{tabular}{|c|c|c|c|c|}
\hline \multirow[t]{3}{*}{ No. } & \multicolumn{4}{|c|}{ MDS analysis dimensions and attributes along with the score } \\
\hline & \multirow[t]{2}{*}{ Dimensions/ attributes } & \multicolumn{2}{|c|}{ Scoring } & \multirow[t]{2}{*}{ Remarks questions and score } \\
\hline & & Good & Bad & \\
\hline $\mathrm{C}$ & Social & & & \\
\hline 1 & Re-generation & 2 & 0 & $\begin{array}{l}\text { Is there anyone in family intends to continue its efforts to be a } \\
\text { farmer?(0)No; (1) hesitated; (2) Yes (Hayati, et al., 2010) }\end{array}$ \\
\hline 2 & $\begin{array}{l}\text { Distance of education } \\
\text { facilities }\end{array}$ & 3 & 0 & $\begin{array}{l}\text { What is the distance that must be traveled to achieve } \\
\text { educational facilities?(0)> } 5 \mathrm{~km} \text {; (1) } 3-5 \mathrm{~km} \text {; (2) } 1.5-3 \mathrm{~km} \text {; (3) } \\
<1.5 \mathrm{~km} \text { (Hayati, et al., 2010) }\end{array}$ \\
\hline 3 & Type of health facility & 3 & 0 & $\begin{array}{l}\text { What kind of health facility closest to where you live? (0) } \\
\text { Nothing (1) clinics; (2) health centers; (3)hospitals (Hayati, et } \\
\text { al., 2010) }\end{array}$ \\
\hline 4 & $\begin{array}{l}\text { Distance of health } \\
\text { facilities }\end{array}$ & 3 & 0 & $\begin{array}{l}\text { What is the distance that must be traveled to reach the nearest } \\
\text { health facility?(0)<1km; (1) } 1-3 \mathrm{~km} \text {; (2) } 3-5 \mathrm{~km} \text {; (3)> } 5 \mathrm{~km} \\
\text { (Hayati, et al., 2010) }\end{array}$ \\
\hline 5 & Farmers liveliness & 2 & 0 & $\begin{array}{l}\text { Is the farmer groups still active?(0)No, }(1) \text { sometimes there is } \\
\text { activity; (2) active (Ministry of Agriculture, 2018) }\end{array}$ \\
\hline 6 & Farmers Participation & 2 & 0 & $\begin{array}{l}\text { Are farmers actively participating in the planning process of } \\
\text { government program?(0) Never; (1) sometimes; (2) often } \\
\text { (Hayati, et al., 2010) }\end{array}$ \\
\hline 7 & Source of information & 2 & 0 & $\begin{array}{l}\text { Where the source of information about the agricultural } \\
\text { program of the government obtained? }(0) \text { no; (1) The farmers } \\
\text { group; (2) The weekly activities village office (Hayati, et al., } \\
2010)\end{array}$ \\
\hline 8 & $\begin{array}{l}\text { The availability of } \\
\text { complaints platforms }\end{array}$ & 2 & 0 & $\begin{array}{l}\text { Is there a government platforms to accommodate complaints } \\
\text { about agricultural problems? (0) No;(1) There is, but the } \\
\text { response is slow; (2) There and rapid response (Hayati, et al., } \\
2010)\end{array}$ \\
\hline 9 & $\begin{array}{l}\text { Government } \\
\text { responsiveness }\end{array}$ & 2 & 0 & $\begin{array}{l}\text { How the government's response to the complaints / reports } \\
\text { from farmers about drought damage and irrigation?(0) did not } \\
\text { respond and was not followed up; (1) responded but were not } \\
\text { followed; (2) responded to and acted on (Hayati, et al., 2010) }\end{array}$ \\
\hline 10 & Counseling program & 3 & 0 & $\begin{array}{l}\text { Is counseling and training program of the government still } \\
\text { active?(0) never, (1) sometimes; (2) active and scheduled } \\
\text { (Hayati, et al., 2010) }\end{array}$ \\
\hline 11 & Industrial presence & 2 & 0 & $\begin{array}{l}\text { Is there industries / industrial area around?(0) There are and } \\
\text { many; (1) There is, but not many; (2) No }\end{array}$ \\
\hline 12 & Industrial influence & 2 & 0 & $\begin{array}{l}\text { Is the existence of the industry can help local community } \\
\text { well-being?(0)No; (1) A little help; (2) very helpful }\end{array}$ \\
\hline 13 & Culture of cooperation & 2 & 0 & $\begin{array}{l}\text { What is culture farming in mutual cooperation still activr?(0) } \\
\text { never; (1) sometimes; (2) routine (Hayati, et al., 2010) }\end{array}$ \\
\hline
\end{tabular}




\section{Results and Discussion}

Current condition obtained from observations and surveys at the study location found in the West Telukjambe District has entered the third season at the stage of soil treatment and prevention of pests. However, at some point there is land drought and there is no activity in land management (Figure 2).

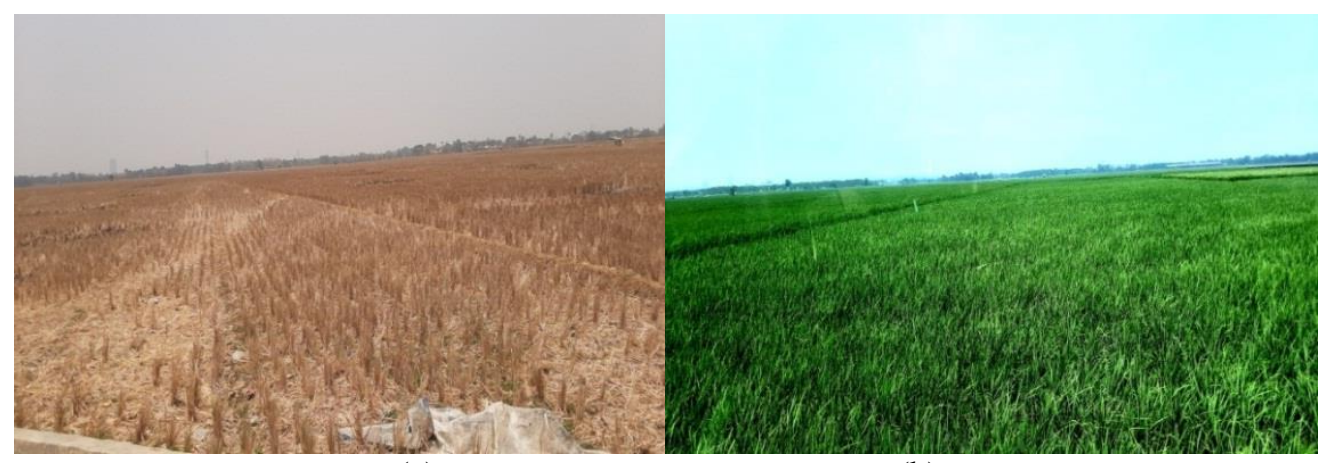

(a)

(b)

Fig. 2. (a) drought paddy fields (b) of wetland that is processed in a period of treatment

(Observations, 25 September 2019)

Respondents in this research 96 people who work as farmers. Characteristics of respondents from the the questionnaire in this study is $98 \%$ of male, with age range from 45 years - 80 years and included in the category of productive into elderly. The education level of $69 \%$ respondents are primary school graduated and $100 \%$ native inhabitants of West Telukjambe.

\section{Diagram of Farmers Sustainability Index}

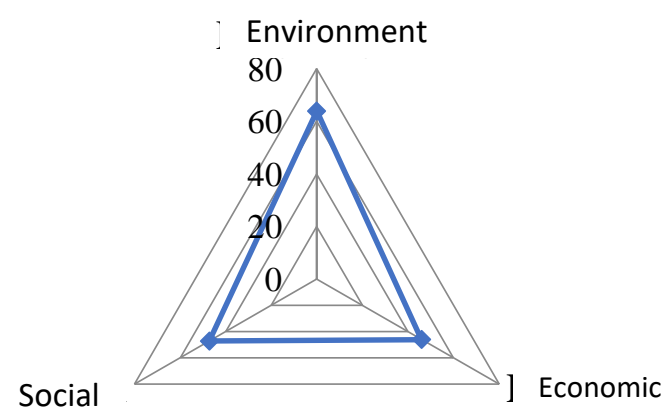

Fig. 3 Diagram of farmers sustainability index in the West Telukjambe

The results of the primary analysis were generated from simulations is Rapfish ordination (ordinated in each dimension) which is processed by entering attribute scoring 
number. The result of simulation ordination diagram describes the position of the sustainability of each attribute or dimension to the scale of assessment. Sustainability index values generated from each ordination is presented in Figure 3.

The results of multidimensional scaling analysis using the Rapfish presented in Figure 3. The index value of each dimension classified as less sustainable were economic and social dimensions, while for the environmental dimension categorized as quite sustainable.

Index value of each dimension based on the diagram in Figure 3 is in the range $40-65$. Environmental dimension that has the highest index value of 63.89. Dimensions with the lowest index value is the economic dimension with the value of 46.02 and was followed by the index of the social dimension with the index value of 47.19. Results Rapfish analysis for the environmental dimension is shown in Figure 4.

\section{RAPFISH Ordination Environment Dimension}

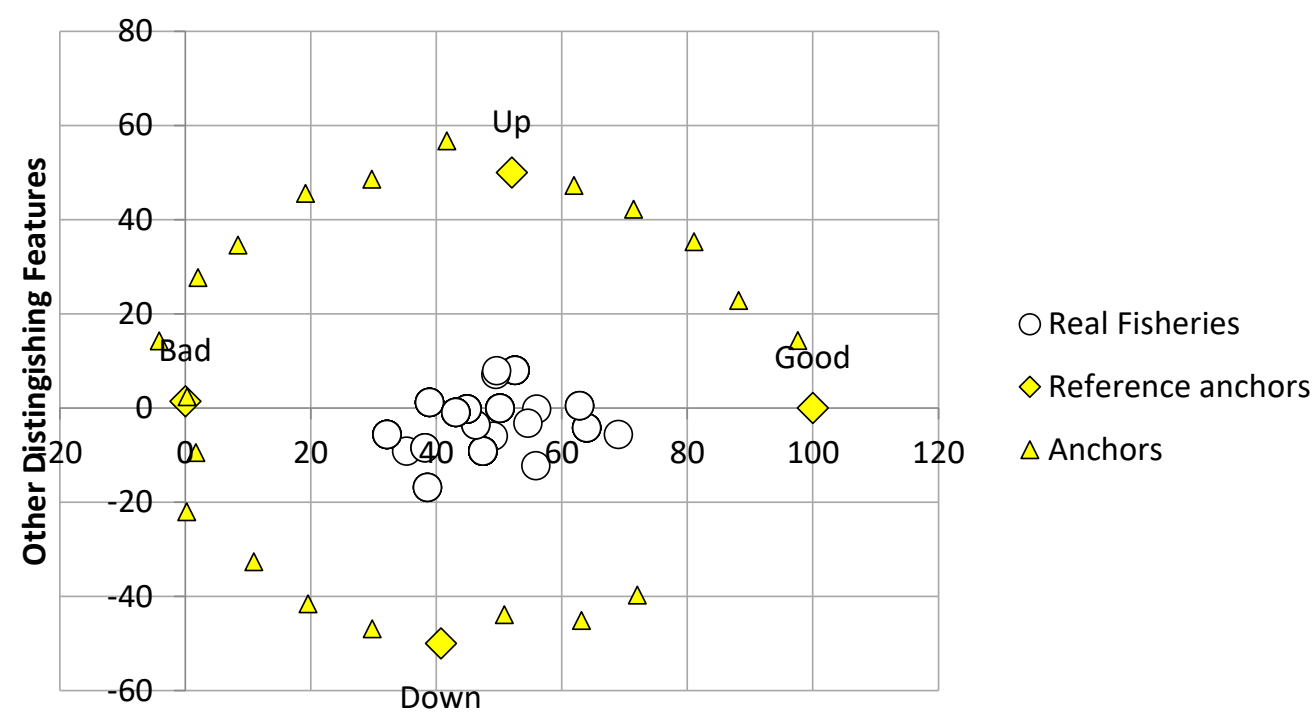

Fisheries Status

Fig. 4 Diagram of Rapfish Sustainability Index for Environment Dimension

Figure 4 shows the majority of farmers are represented by real fisheries in the diagram is the status value range 60-70 are included in the category of quite sustainable. The status indicates wetland management practices by the farmers in the district of West Telukjambe still supported by the adequacy of natural resources that support agricultural environment farmers. This is supported by the productivity of paddy fields are still high with average productivity reached 6-7 tons / ha. 
Then, for each attribute analysis results leverage environmental dimensions shown in Figure 5. Figure 5 illustrates the sensitivity of each of the attributes if the RMS value of an attribute the higher, the more effect on the change in value of the dimension of sustainability indexes. Attributes that have a high sensitivity to the environmental dimension is that has a

\section{Diagram of Sensitivity Attribute Environment Dimension}

$$
\begin{aligned}
& \text { Irrigation type } \\
& \text { Irrigation quality }
\end{aligned}
$$

The adequacy of irrigation discharge

$$
\begin{array}{r}
\text { Irrigation physical condition } \\
\text { Irrigation water source } \\
\text { Irrigation type } \\
\text { Productivity } \\
\text { Pesticide intensity } \\
\text { Fertilizer subsidies } \\
\text { Area of land ownership } \\
\text { Types of land ownership }
\end{array}
$$
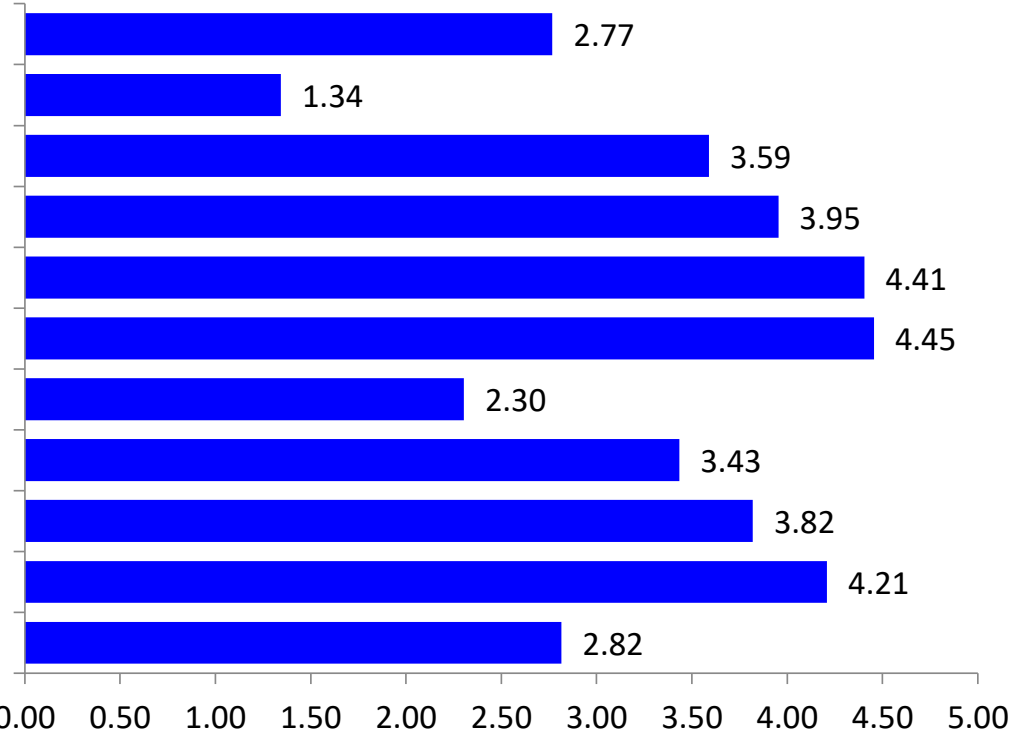

Root Mean Square Change \% in Ordination when Selected Attribute Removed (on Status scale 0 to 100)

RMS value above 2.5 or above scale 50 .

Fig. 5 Diagram of Sensitivity Attribute Environment Dimension

In Figure 5 there are nine attributes that have high sensitivity values. The first and second sensitive attribute is the type of irrigation to the RMS value of 4.45 and a source of irrigation to the RMS value of 4.41. Type of irrigation used in paddy fields all respondents are technical irrigation comes from surface water. The type and source of irrigation is suitable for the District of West Telukjambe with relatively flat topography. If both attributes are omitted, would have a significant effect of both of these attributes RMS value against the value of the environmental dimension of sustainability indexes. The third attribute is a sensitive area of land ownership. Amounting to $68.75 \%$ of the total respondents have land to private ownership by as much as $33.33 \%$ distribution has a land area from 0.1 to 0.5 ha, $18.75 \%$ have a land area of 0.51 to 1 ha, $18,75 \%$ farmers owned $0,51-1$ ha, and $16,67 \%$ owned $1,1-1,5$ ha.

Next analysis is the economic dimension of sustainability indexes. The economic dimension of sustainability has the lowest index value compared to the other two dimensions. Results ordinated economic dimensions shown in Figure 6. 


\section{RAPFISH Ordination Economic Dimension}

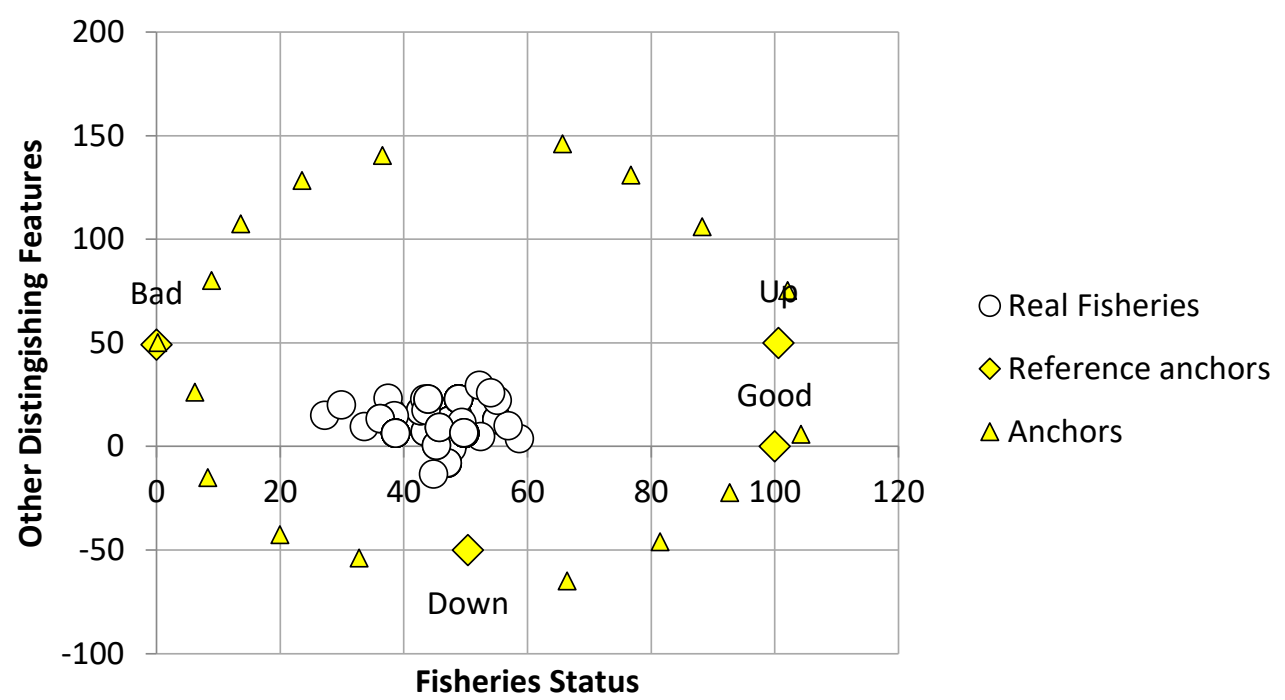

Fig. 6 Diagram of Rapfish Sustainability Index for Economic Dimension

Figure 6 shows the respondents were represented by real fisheries in the diagram at scale 20-50 with less sustainable categories. The status indicates activity land management by the farmers not produce sufficient economic value of life of farmers. this is supported by the incomes from farming less than the cost of basic needs that must be covered. Revenues earned from 55.21\% of respondents earned 2-3 million / month, 29\% earned 1-2 million / month, $8.33 \%$ earned 3-4 million / month, $4.17 \%$ earned $<1$ million / month, and 3.13\% earned 4-5 million / month. The average income of respondents in the District of West Telukjambe between 1-3 million / month. The revenue is lower than expenditure per month to be paid by respondents. Average expenditure per month of the respondents are more than 3 million / month. This value is only for necessities, exclude education needs, transportation and others. The attributes that most influence on the value of the economic dimension farmer sustainability index presented in Figure 7. 


\section{Diagram of Sensitivity Attribute Economic Dimension}

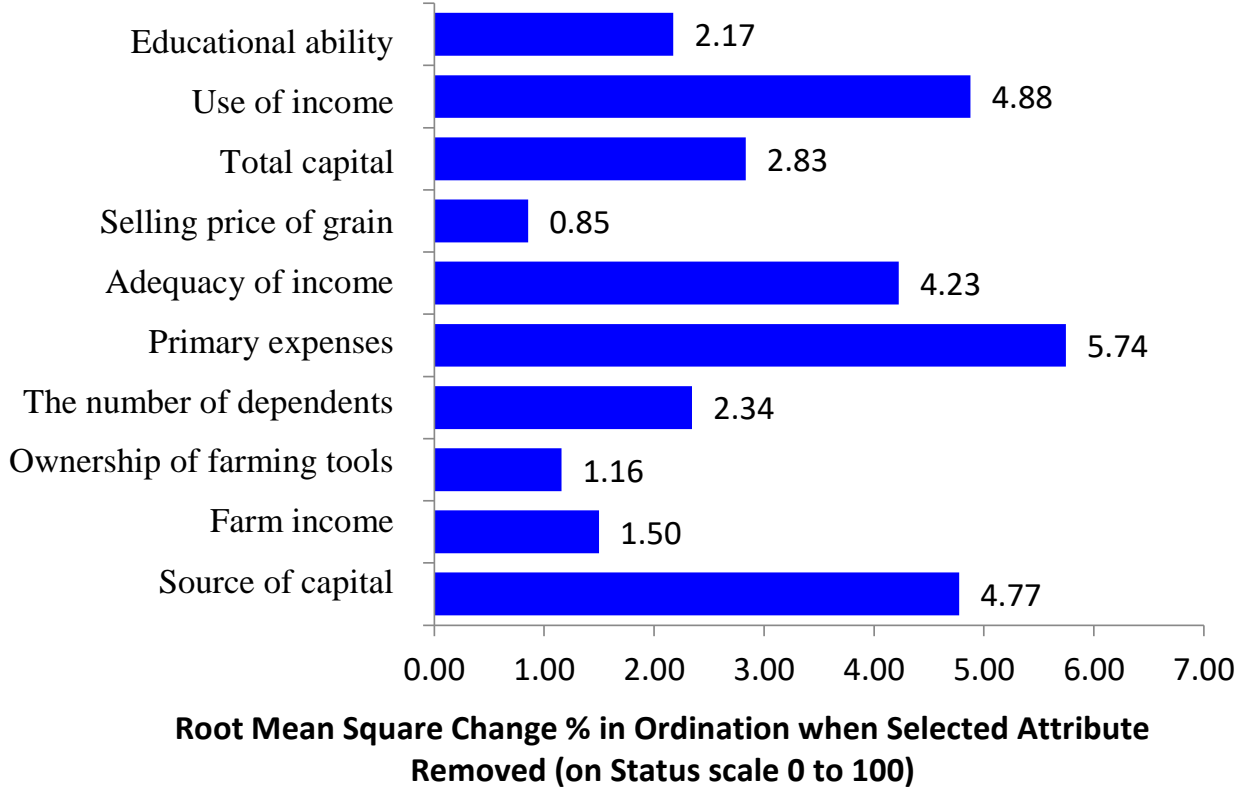

Fig. 7 Diagram of Sensitivity Attribute Economic Dimension

Figure 7 shows that there are four attributes with values of sensitivity over a scale 50 or 3.5. The first attribute is the primary expenses attribute with the RMS value of 5.74. The second is the use of income attributes with the RMS value of 4.88. The average income of farming can only be used by the respondent for the basic needs. The third sensitive attribute is source of capital. As many as $99 \%$ of respondents use capital from their own pocket without loans, and $1 \%$ were relying on private sources and loans. If the attribute is omitted capital resources, the sustainability index farmers from the economic side will be affected significantly because farming capital became one of the main factors of agricultural production. The fourth sensitive attribute is the adequacy of income. Among the 10 attributes, there are 6 other attributes that are not sensitive. The first non sensitive attributes is the total capital with the RMS value of 2.83. the number of dependents with RMS values of 2.34 , educational ability with RMS value 2.17 , farmers' income with RMS value 1.5 , ownership of farming tools with RMS value 1.16, and selling price of grain with RMS value 0.85 . 
Next up is the result of analysis of the sustainability of the social dimension. The value of the social dimension of sustainability indices including less sustainable categories shown in Figure 8.

\section{RAPFISH Ordination Social Dimension}

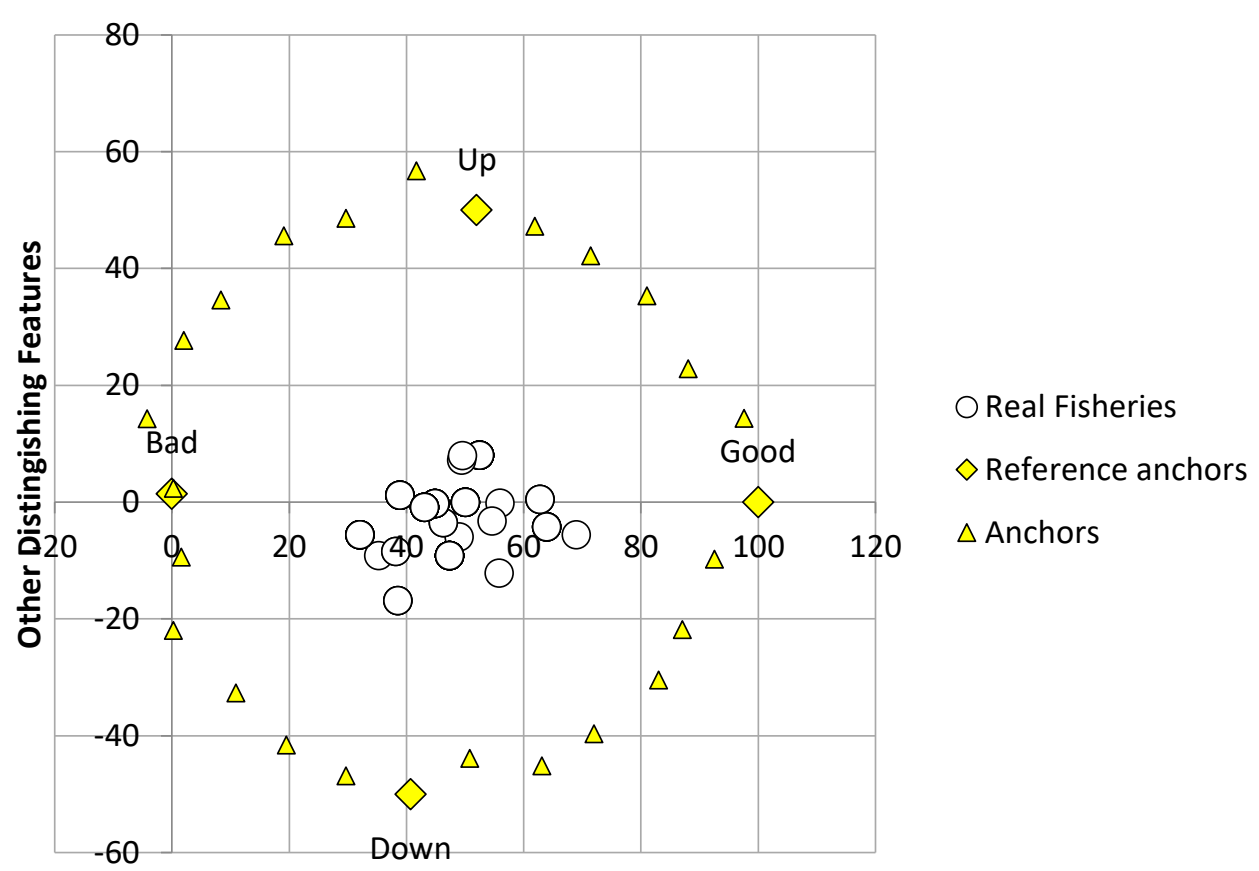

Fisheries Status

Fig. 8 Diagram of Rapfish Sustainability Index for Social Dimension

Figure 8 shows the position of the respondents were represented by real fisheries in the diagram is in the range of less sustainable categories. The index value indicates farmers land management activities in the District of West Telukjambe unsustainable from social dimension. It is caused by several things including regeneration. Amounting to $88 \%$ of the total respondents expressed no wish to become the next generation as a farmer in the family. In addition, other attributes that affect the sustainability of the farmers in the district of West Telukjambe of the economic dimension is illustrated in Figure 9 along with the level of sensitivity. 


\section{Diagram of Sensitivity Attribute Social Dimension}

The culture of cooperation Industrial influence Industrial presence

Counseling program

Government response The availability of complaints platforms

Source of information

Farmer participation

Farmer liveliness

Distance of health facilities

Types of health facilities

Distance of education facilities

Re-generation

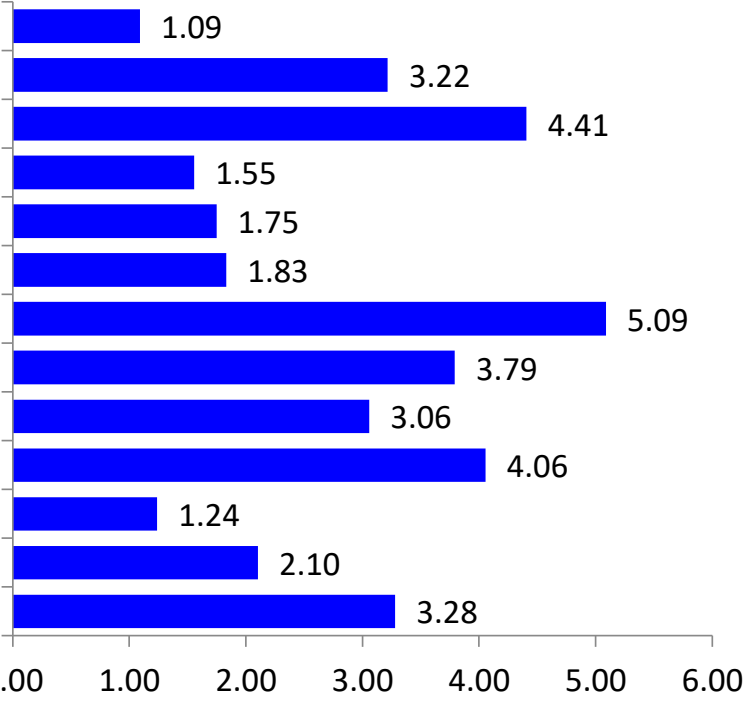

Root Mean Square Change \% in Ordination when Selected Attribute

Removed (on Status scale 0 to 100)

Fig. 9 Diagram of Sensitivity Attribute Social Dimension

Figure 9 shows that there are seven attributes sensitive to the RMS value above 3 or above scale 50. The first sensitive attribute is the source of information with the RMS value of 5.09. if this attributes eliminated, it would affect significantly the value of sustainability index of economic dimension. It was because of the presence of resources that are $100 \%$ derived from weekly activities villages reflect their activities aimed at informing and in order to help farmers know the developments surrounding agricultural activities conducted by local government. The second sensitive attribute is the industrial presence with the RMS values by 4.41. The existence of the industry in the District of West Telukjambe increasing by the amount but did not provide a positive influence for the improvement of living standards, especially farmers. The third sensitive attribute is the farmers participation with the RMS value of 3.79. Participation of farmers should be increased in order to improve the integration between the needs of farmers and agricultural programs organized by the government to be more effective and efficient.

After analysis of leverage is the Monte Carlo analysis. Monte Carlo analysis was done to calculate the uncertainty value and will be compared with the value of the Rapfish MDS analysis result. The results of Monte Carlo analysis is shown in Table 2. 
Table 2 Value of Monte Carlo Analysis

\begin{tabular}{lrrr}
\hline \multicolumn{1}{c}{ Dimension } & \multicolumn{1}{c}{$\begin{array}{l}\text { Value of } \\
\text { Rapfish }\end{array}$} & $\begin{array}{c}\text { Value of Monte } \\
\text { Carlo }\end{array}$ & $\begin{array}{c}\text { Difference between } \\
\text { rapfish and monte carlo }\end{array}$ \\
\hline Environment & 63,89 & 63,57 & 0,32 \\
Economic & 46,02 & 46,14 & 0,12 \\
Social & 47,19 & 47,2 & 0,01 \\
\hline
\end{tabular}

Table 2 shows the results of Monte Carlo analysis and Rapfish difference is not more than $5 \%$ for all dimensions. The difference in value Rapfish and Monte Carlo analysis for the environmental dimension of 0.32 , on the economic dimension of 0.12 and 0.01 for the social dimension. The difference value $<5 \%$, which means the value of the analysis result Rapfish has a confidence level exceeds $95 \%$. Values that exceed the confidence level of $95 \%$ indicates that the MDS models built in this study was adequated to estimate the sustainability of farmers in the district of West Telukjambe. Next is the analysis of the accuracy (Goodness of fit) to determine the outcome of MDS analysis in this study is adequate. Goodness of fit analysis results are shown in Table 3 .

Table 3 Goodnees of fit of S-stress and RMS

\begin{tabular}{lrrr}
\hline Value/Dimension & Environment & Economic & Social \\
\hline Stress & 0,16 & 0,17 & 0,16 \\
RSQ & 0,94 & 0,96 & 0,93 \\
\hline
\end{tabular}

Table 3 shows the value of stress and RSQ for each dimension. The Stress value of the three dimensions in the range $0,16-0,17$, while the value of the RSQ is in the range 0.93 to 0.96. Stress value less than 0.25 and the value of RSQ more than $90 \%$ even close to $100 \%$ indicates MDS analysis model in this study have high precision pick and preparation in accordance with the attributes of each dimension.

\section{Conclusion}

Sustainability status of farmers in the district of West Telukjambe currently for 3dimensional and overall is in less sustainable category. From the third dimension, the economic dimension has the lowest index value, followed by social dimensions, and then the environmental dimension. Some attribute identified sensitive to the sustainability of farmers in West Telukjambe. These attributes include the status and ownership of land, capital costs, and regeneration. Government commitment is required not only to protect sustainable agriculture, but also a commitment to ensure sustainable farmers to improve land ownership attributes, irrigation discharge, and efficiency of capital costs incurred farmers to be balanced with revenue generated from land management practices. 
Acknowledgments. We thank University of Indonesia who have supported this research financially through grants PITMA Universitas Indonesia Number: NKB-1020 / UN2.R3.1 / HKP.05.00 / 2019.

\section{References}

[1] Baker, J. L. (2012). Climate Change, Disaster Risk, and the Urban Poor: Cities Building Resilience for a Changing World: World Bank Publications.

[2] Central Bureau of Statistics (BPS). 2010. Karawang Regency in Figures 2010. Karawang: Central Central Bureau of Statistics Karawang Regency.

[3] Central Bureau of Statistics (BPS). 2017. Karawang Regency in Figures 2017. Karawang: Central Central Bureau of Statistics Karawang Regency.

[4] Central Bureau of Statistics (BPS). 2018. Karawang Regency in Figures 2018. Karawang: Central Central Bureau of Statistics Karawang Regency.

[5] Central Bureau of Statistics (BPS). 2010. West Telukjambe District in Figures 2010. Karawang: Central Central Bureau of Statistics Karawang Regency.

[6] Central Bureau of Statistics (BPS). 2011. West Telukjambe District in Figures 2011. Karawang: Central Central Bureau of Statistics Karawang Regency.

[7] Central Bureau of Statistics (BPS). 2018. The Result of Inter-Census Agricultural Survey. Central Bureau of Statistics.

[8] Central Bureau of Statistics (BPS). 2017. Agriculture Indicator 2017. Central Bureau of Statistics. [9] Cotterell et al. (2008). Measuring Changes in Family and Whanau Well-being Using Census Data, 1981-2006: A Preliminary Analysis. Statistics New Zealand, Wellington.

[10] Baker, J. L. (2012). Climate Change, Disaster Risk, and the Urban Poor: Cities Building Resilience for a Changing World: World Bank Publications.

[11] Gough et al. (2007). Theorizing well-being in international development. In I. Gough, \& J. A. McGregor (Eds.),Wellbeingin Developing Countries: from Theory to Research. Cambridge University Press.

[12] Hayati, D., Ranjbar, Z., \& Karami, E. (2010). Measuring agricultural sustainability. In Biodiversity, biofuels, agroforestry and conservation agriculture (pp. 73-100). Springer, Dordrecht.

[13] Kavanagh, P., \& Pitcher, T. J. (2004). Implementing microsoft excel software for rapfish: A technique for the rapid appraisal of fisheries status.

[14] Ministry of Agriculture. 2018. Agricultural Statistics 2018. Center for Agricultural Data and Information Systems Ministry of Agriculture Republic of Indonesia.

[15] Ministry of Industry. (2015). National Industrial Development Master Plan 2015-2035. Jakarta

(ID): Ministry of Industry.

[16] Pitcher, T. J., \& Preikshot, D. (2001). RAPFISH: a rapid appraisal technique to evaluate the sustainability status of fisheries. Fisheries Research, 49(3), 255-270.

[17] Pitcher, T.J., M.E. Lam, C. Ainsworth, A. Martindale, K. Nakamura, R.I. Perry, and T. Ward. 2013. Improvements to Rapfish: A Rapid Evaluation Technique for Fisheries Integrating Ecological and Human Dimensions. Journal of Fish Biology 83(4): 865-889.

[18] Rustiadi, E. (2007). Analisis Spasial Permasalahan Pembangunan Kawasan JABODETABEK. In Makalah pada Seminar Menuju Jabodetabek Berkelanjutan. IPB ICC. Bogor.

[19] Reig-Martínez, E., Gómez-Limón, J. A., \& Picazo-Tadeo, A. J. (2011). Ranking farms with a composite indicator of sustainability. Agricultural economics, 42(5), 561-575.

[20] Roessali, W., Ekowati, T., \& Prasetyo, E. (2019, March). Economic aspects of soybean farming sustainability in Central Java, Indonesia. In IOP Conference Series: Earth and Environmental Science (Vol. 250, No. 1, p. 012022). IOP Publishing.

[21] Subekti, S., \& Sunartomo, A. F. (2019, March). Achieving sustainable agriculture through enhancing agricultural extension institution. In IOP Conference Series: Earth and Environmental Science (Vol. 250, No. 1, p. 012011). IOP Publishing. 
[22] Supriatna, S., Taqyuddin, T., \& Putri, A. A. (2018, October). Agricultural landscape sustainability in Sinarresmi Indigenous Village, West Java, Indonesia. In AIP Conference Proceedings (Vol. 2023, No. 1, p. 020182). AIP Publishing.

[23] Thamrin, S.H. Sutjahjo, C. Herison, dan S. Sabiham. 2007. Analisis Keberlanjutan Wilayah Perbatasan Kalimantan Barat Malaysia untuk Pengembangan Kawasan Agropolitan. Jurnal Agro Ekonomi. JAE ,25 (2):103-124.

[24] White, S. C. (2009). Analyzing well-being: a framework for development practice. Development in Practice, 20(2), 158-172. 